\title{
MRS Seeks Nominations for Fall 1993 Awards: Von Hippel Award, MRS Medal, and David Turnbull Lectureship
}

Nominations are being accepted for the 17th annual Von Hippel Award, the MRS Medal, and the second David Turnbull Lectureship, scheduled for presentation at the 1993 MRS Fall Meeting in Boston.

These awards have been established to recognize excellence, innovation, and enterprise in materials research, and they enjoy a well-earned prestige. Awards Committee Chair John E.E. Baglin urges you to participate by nominating a colleague for one of these upcoming awards. Complete nomination packages for the awards are due by July 1, 1993 to: John B. Ballance, Executive Director, Materials Research Society, 9800 McKnight Road, Pittsburgh, PA 15237; phone (412) 367-3003; fax (412) 367-4373 .

For nomination forms and details about eligibility and nomination criteria, please contact Anne Wagner at the above address. It is especially important that those submitting nominations prepare the nomination packages carefully and address all the criteria. Nominations must be brief and succinct, as specified in the rules. Preparing a nomination for a strong candidate is not unduly arduous, and you are encouraged to think seriously about who might deserve to be nominated for one of these honors.

\section{Von Hippel Award Recognizes Interdisciplinary Scientific Work with a Significant Impact on Materials Research}

The Von Hippel Award, first presented to its namesake Arthur R. von Hippel in 1977, is the Materials Research Society's highest honor. An international hallmark of excellence and distinction, the award recognizes those qualities most prized by materials scientists and engineersbrilliance and originality of intellect, combined with vision that transcends the boundaries of conventional scientific disciplines. The award includes a $\$ 5,000$ cash prize and a unique trophy-a mounted ruby laser crystal symbolizing the manyfaceted nature of materials research.

Nominees for the Von Hippel Award must have outstanding scientific credentials, and their scientific work must have had a significant impact on materials research and must have exemplified an interdisciplinary approach. The nominee's scientific discipline is of no concern except that the work must have been in areas commonly associated with materials research. The nominee does not need to be a member of MRS or to have previously won other major awards, and nominees of any nationality are eligible.

The recipient is determined by a vote of the MRS Council from the slate of candidates prepared by the Awards Committee. Nominations for the Von Hippel Award remain under consideration for three years and may be updated.

\section{MRS Medal Recognizes an Exceptional Recent Achievement in Materials Research}

Nomination for the MRS Medal is open to scientists and engineers who have, in recent years, been responsible for a major advance in any materials-related field of research. The impact of their materials research on the relevant materials field will be a primary consideration in making the awards. The Medal may recognize such impact within a larger traditional field or in a more specialized or developing field. Preference will generally be given to nominations for work that has not previously received appropriate award recognition. Nominations remain under consideration for three years and may be updated by the nominator during that time.

Nominees need not be members of MRS, and nominees of any national origin or citizenship are eligible. Current members of the MRS Awards Committee and MRS officers are not eligible. A Medal will normally be awarded to one individual for a cited achievement. If collaborators for a single achievement are each found to merit recognition on their own merits, then each may be regarded as a candidate for a Medal, and judged by the above criteria.

In addition to an engraved and mounted Medal, awardees receive a $\$ 1,000$ cash prize. Each Medalist will be invited to present a general-interest talk describing his/her work, to be featured within the structure of the meeting at which the Medal is awarded. 


\section{MRS Medalists}

Arthur J. Freeman (1990), Northwestern University, "in recognition of his pioneering achievements in the field of monolayer and lowdimensional magnetism."

Duward F. Shriver (1990), Northwestern University, "in recognition of his seminal work in the synthesis, characterization, understanding, and application of polymer-based solid electrolyte materials."

Bernard S. Meyerson (1991), IBM T.J. Watson Research Center, "in recognition of his dynamic research leading to the fabrication of highspeed heterojunction bipolar transistors."

Shigeyuki Sōmiya (1991), NishiTokyo University, "in recognition of his innovation and energy in pioneering the field of hydrothermal synthesis of ceramic materials."

L. Eric Cross (1992), Pennsylvania State University, "in recognition of his leadership and vision in the atomic-scale engineering of relaxor ferroelectric materials as the prototype of self-assembling nanocomposites."

Stephen J. Pennycook (1992), Oak Ridge National Laboratory, "for the development and application of incoherent (Z-contrast) imaging in the scanning transmission electron microscope for direct determination of the atomic-scale structure and chemistry of materials and interfaces."

\section{David Turnbull Lectureship Recipient}

Thomas R. Anthony (1992), General Electric Research and Development Center, "for outstanding contributions to the understanding of diffusion, thermomigration, and the synthesis of diamond."

\section{Turnbull Lectureship Honors Materials Science Career Achievement in Research, Writing, Lecturing}

The annual David Turnbull Lectureship, now in its second year, recognizes the career of a scientist who has made outstanding contributions to understanding materials phenomena and properties through research, writing, and lecturingas exemplified by the life work of David Turnbull. The Lectureship is also a means for the recipient to share his/her insights through lectures and articles.

The Turnbull Lecturer receives a $\$ 2,000$ honorarium and a citation plaque. The award includes travel expenses to the MRS meeting at which the Turnbull Lecture is given, as well as additional funds to enable the recipient to speak as the Turnbull Lecturer for MRS Sections and University Chapters.

Nominations for the Turnbull Lecturership may be made for scientists and engineers in all areas of materials science. The primary consideration in making the award is the nominee's career contribution to the fundamental understanding of materials phenomena and properties, through research, writing, and lecturing.

Nominees need not be members of MRS, and nominees of any national origin or citizenship are eligible. Current members of the MRS Awards Committee, MRS officers, and previous Turnbull Lecturers are not eligible. Nominations remain under consideration for three years and may be updated by the nominator during that time.

\section{MRS Awards Committee}

\section{Chair:}

John E.E. Baglin

IBM Almaden Research Center

650 Harry Road, K34/803

San Jose, CA 95120-6099

Phone (408) 927-2280

Fax (408) $927-2100$

\section{Subcommittee Chairs:}

Lynn E. Rehn,

Graduate Student Awards

J. Murray Gibson, MRS Medal

Rodney C. Ewing, Outstanding

Young Investigator Award

Frans Spaepen,

Turnbull Lectureship

G. Slade Cargill III,

Von Hippel Award

\section{Members:}

Thomas R. Anthony

Harry A. Atwater

Bill R. Appleton

Michael J. Aziz

John C. Bravman

Walter L. Brown

John P. de Neufville

Gregory C. Farrington

D. Wayne Goodman

Carl C. Koch

Gregory J. McCarthy

Gary L. McVay

Steve Pennycook

Alan I. Taub

Michael M.J. Treacy

Alice E. White

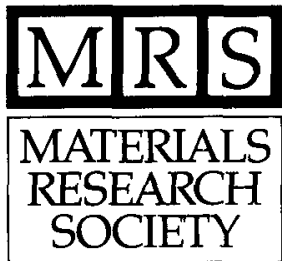

